TWO NEW SPECIES OF BARNACLES (CIRRIPEDIA THORACICA) FROM MINDANAO, PHILIPPINES

AUTHOR(S):

Rosell, Neon C.

\title{
CITATION:
}

Rosell, Neon C.. TWO NEW SPECIES OF BARNACLES (CIRRIPEDIA THORACICA) FROM MINDANAO, PHILIPPINES. PUBLICATIONS OF THE SETO MARINE BIOLOGICAL LABORATORY 1975, 22(1-4): 105-115

ISSUE DATE:

1975-07-31

URL:

http://hdl.handle.net/2433/175887

RIGHT: 


\title{
TWO NEW SPEGIES OF BARNAGLES (GIRRIPEDIA THORAGICA) FROM MINDANAO, PHILIPPINES ${ }^{1)}$
}

\author{
NEON C. ROSELL \\ Department of Zoology, College of Arts and Sciences \\ University of the Philippines
}

With Text-figures $1-4$

The cirriped fauna around Mindanao Island, Philippines, like most areas of the country, has so far not yet been extensively worked out by any local investigator. Few species had been reported from this area in the past. This is on account of some passing collections undertaken by foreign workers either individually or as expedition members who happened to obtain some specimens from the southern islands.

This paper is an initial attempt to study exhaustively the cirripeds inhabiting this part of the Philippines. Another paper is in preparation that will include several species collected around the vicinity of Dipolog and Dapitan Cities, Zamboanga del Norte, Philippines. The species described in this paper were collected on April 1, 1973. Both species were found attached to a sheltered undersurface of small intertidal rocks, in association with Chthamalus moro, a juvenile Tetraclita sp. and a brachyuran decapod, Hyastinus diacanthus where some of the present forms were seated on its carapace together with $C$. moro. It is interesting to note that they were encountered only on rocks lying close to the lowest low tide level where it is always moist and not exposed for any long period.

Reported in this paper is a tetraclitellan, Tetraclitella hyastina and a balanomorph, Balanus (Chirona) tuberculatus which are proposed here as new to science. The type specimens are deposited in the Department of Zoology, Gollege of Arts and Sciences, University of the Philippines as part of its crustacean collections. The number that they bear are those of that collection.

Type Locality. Sicayab, Dipolog City, Zamboanga del Norte, Philippines. Approximately $123^{\circ} 20^{\prime} 32^{\prime \prime}$ E. long. $8^{\circ} 38^{\prime} 8^{\prime \prime} \mathrm{N}$. lat.

\section{Systematic Account}

ORDER THORACICA Darwin, 1854

SUBORDER BALANOMORPHA Pilsbry, 1916

Family Balanidae Leach, 1817

1) Supported by a grant in aid from the NSDB-UP Integrated Research Project No. 7302 Ag.

Publ. Seto Mar. Biol. Lab., XXII (1/4), 105-115, $1975 . \quad$ (Article 6) 


\section{Subfamily Balaninae Leach, 1817 \\ Genus Balanus Da Costa, 1778 \\ Subgenus Chirona Gray, 1835}

Definition. Parietes and radii solid; radii narrow or wide, with thin, smooth or sometimes weakly crenulated sutural edges; orifice conspicuously toothed; basis calcareous; scutum striated longitudinally; tergal spur moderately long, not tapering.

\section{Balanus (Chirona) tuberculatus sp. nov.}

Fig. 1, r-x and Fig. 2, r-y.

Description. Shell small (Fig. 1, x) clear white, with broad prominent longitudinal hyaline or milky white bands, usually 3 on rostrum, 2 on lateralia and 1 on carina; those on rostral plate situated along their sutural edges and on median area, which sometimes may appear divided into 2; on lateralia, a single band along radii side, the other one on the middle of the plate; on carina, this band is situated at the middle of the plate more or less opposite to the median band of rostrum. Carinolatera narrow without distinct band, although a very narrow white line along its radii side may be perceptible. Orifice ovate, distinctly toothed, apices of carina and carinolaterals reflexed. Radii extremely narrow, sometimes could be mistaken as absent, with highly oblique summits, sutural edges finely crenulate; alae broad with oblique summits. Compartments roughened by small bead-like tubercles along growth ridges; persistent epidermis hirsute. Internally snow-white, sheath about $1 / 2$ to $2 / 3$ with distinct horizontal growth ridges, inferior edge free (Fig. 1, t); paries below longitudinally ribbed more distinct toward their bases, basis of these ribs are perceptibly denticulate (Fig. 1, w). Basis calcareous, peripherally porous.

Sizes: carinorostral diameter; orifice, from $1.25 \mathrm{~mm}$ to $3.7 \mathrm{~mm}$; base, from 6.6 $\mathrm{mm}$ to $9.3 \mathrm{~mm}$; height, from $3.0 \mathrm{~mm}$ to $4.3 \mathrm{~mm}$.

Scutum (Fig. 2, r \& t) dirty white, semitransparent, triangular; occludent margin toothed, longer than the basal and tergal margins; basal margin rounded toward basitergal angle. Externally (Fig. 2, r) medially slightly depressed, ends outwardly bent; horizontal growth ridges with sharp triangular denticles longitudinally arranged imparting a striated appearance to the valve; hirsute. Internally (Fig. 2, t) white, smooth; articular ridge moderate; articular furrow narrow and shallow; adductor ridge distinct running parallel to the articular ridge; pit for adductor muscle faintly indicated; crests for the depressor muscles obsolete.

Tergum semitransparent, white, subtriangular, beaked and flat; spur moderate, transversely pointed about $1 / 2$ of basal margin, fasciole very shallow; externally horizontal growth ridges quite distinct, hirsute; scutal margin slightly concave: internally (Fig. 2, s) white; articular ridge prominent; articular furrow broad and shallow; crests for the depressor muscles faintly indicated.

The numbers of segments of the cirri: 


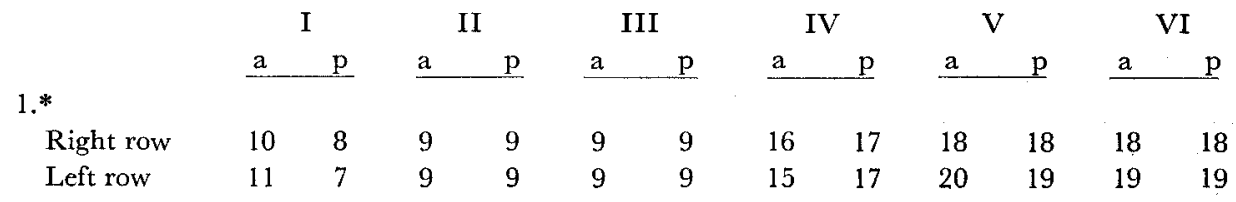

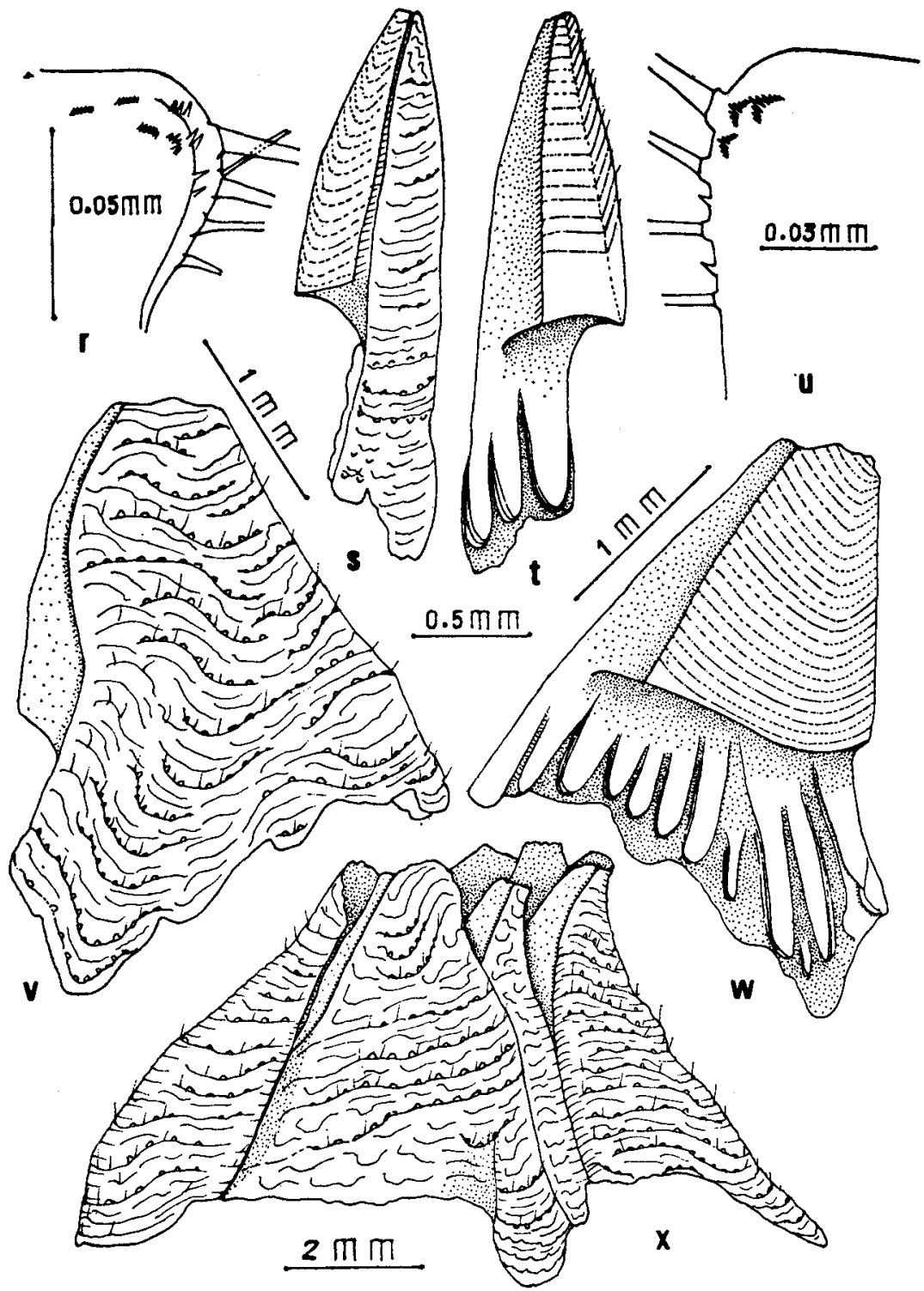

Fig. 1. Balanus (Chirona) tuberculatus sp. nov. r, 5th segment of anterior ramus of cirrus III; s, carinolateral compartment, outer side view; $t$, carinolateral compartment, inner side view; $u$, 6 th segment of anterior ramus of cirrus VI; $v$, lateral compartment, outer side view; $w$, lateral compartment, inner side view; $\mathrm{x}$, undissected animal, external view. ( $\mathrm{r} \& \mathrm{x}$, holotype; $\mathrm{s}, \mathrm{t}$, u, v, \& w, paratype). 


\begin{tabular}{lrrrrrrrrrrrr}
$2 . *$ \\
Right row & 12 & 7 & 10 & 10 & 9 & 8 & 16 & 18 & 19 & 18 & 18 & 18 \\
Left row & 12 & 7 & 9 & 9 & 10 & 9 & 16 & 16 & 18 & 18 & 20 & 20 \\
\hline Holotype & $* *$ Paratype & & & & & & & & & &
\end{tabular}

Rami of cirrus I unequal, anterior ramus longer, basal segments broad, upper ones narrower; posterior ramus shorter, frontal margin of intermediate segments protuberant: frontal margin of intermediate segments of both rami with finely pinnate setae. Rami of cirri II and III contain more or less equal number of segments, however, anterior ramus is usually 2 segments longer than posterior ramus, like posterior ramus of cirrus I frontal margin of intermediate segments protuberant with finely pinnate setae. Cirrus III look similar to cirrus II than to the posterior cirri. In this cirrus there are minute spines and scale-like structures bearing spinelets arising from their margins toward the antero-distal area of both rami (Fig. 1, r \& u). Cirri IV to VI similar, longer than the anterior ones, frontal margin of intermediate segments bears 4 pairs of subequal sparsely pinnate setae with spinules between bases; posterior margin of basal segments furnished with minute spinelets. Penis long, gradually tapering, annulated with few short hairs, near its orifice the hairs are longer. Basidorsal point present.

Mouth parts. Labrum (Fig. 2, y) deeply notched, margin hairy, labral crests with 2 or 3 teeth-like denticles. Palpus club-shaped, apical setae longer and finely pinnate, shorter ones curving and serrate. Mandible (Fig. 2, v) with 5 teeth, 2nd usually bifid, 3rd, 4th and 5th teeth placed closed to each other and the inferior angle. Maxilla I (Fig. 2, u) cutting edge supporting 8 spines, slightly notched below 2 upper large spines, lower part very slightly protuberant supporting 2 large spines, intermediate spines shorter and smaller; inferior angle rounded bearing small straight spines. Maxilla II (Fig. 2, w) bilobed, upper lobe spatulate, margin highly setose; lower lobe smaller, frontal margin strongly convex, margin fringed with few short setae.

Habitat. Several were obtained from the undersurface of small intertidal rocks situated close to the lowest low tide level. These were found in common with Tetraclitella hyastina, another new species. A juvenile stage was found attached to the carapace of a brachyuran decapod Hyastinus diacanthus recovered from the same place together with $C$. moro and a juvenile Tetraclita sp. seated on the same side of the rock surface.

Remarks. The present form closely resembles B. bimae Hoek, 1913 and no doubt falls under this group. Hoek (1913) assigned his species to section Striato-Balanus which is equivalent to Darwin's (1854) Section F. Pilsbry (1916) eventually assigned these species to subgenus Chirona which is followed in this paper. Together with $B$. amaryllis and $B$. taiwanensis, these are the only known real littoral species under the group. Other known members are deep-sea forms.

Externally some of the specimens in the batch look similar to Hoek's illustrations for $B$. bimae, pl. XVI, Fig. 5. Like his species the scuta are longitudinally striated 
in a way resembling Pilsbry's (1916) B. krugeri too, pl. 52, Fig. 1 and $1 \mathrm{c}$. The present form is also related to $B$. taiwanensis Hiro, 1939 with regard to the narrow carinolateral compartment, a longitudinally striated scuta and a similar habitat, both being hypobiotic like the tetraclitellans. However, the present species has shorter rami, segments bear 4 pairs of setae and a porous calcareous basis, at least peripherally, instead of

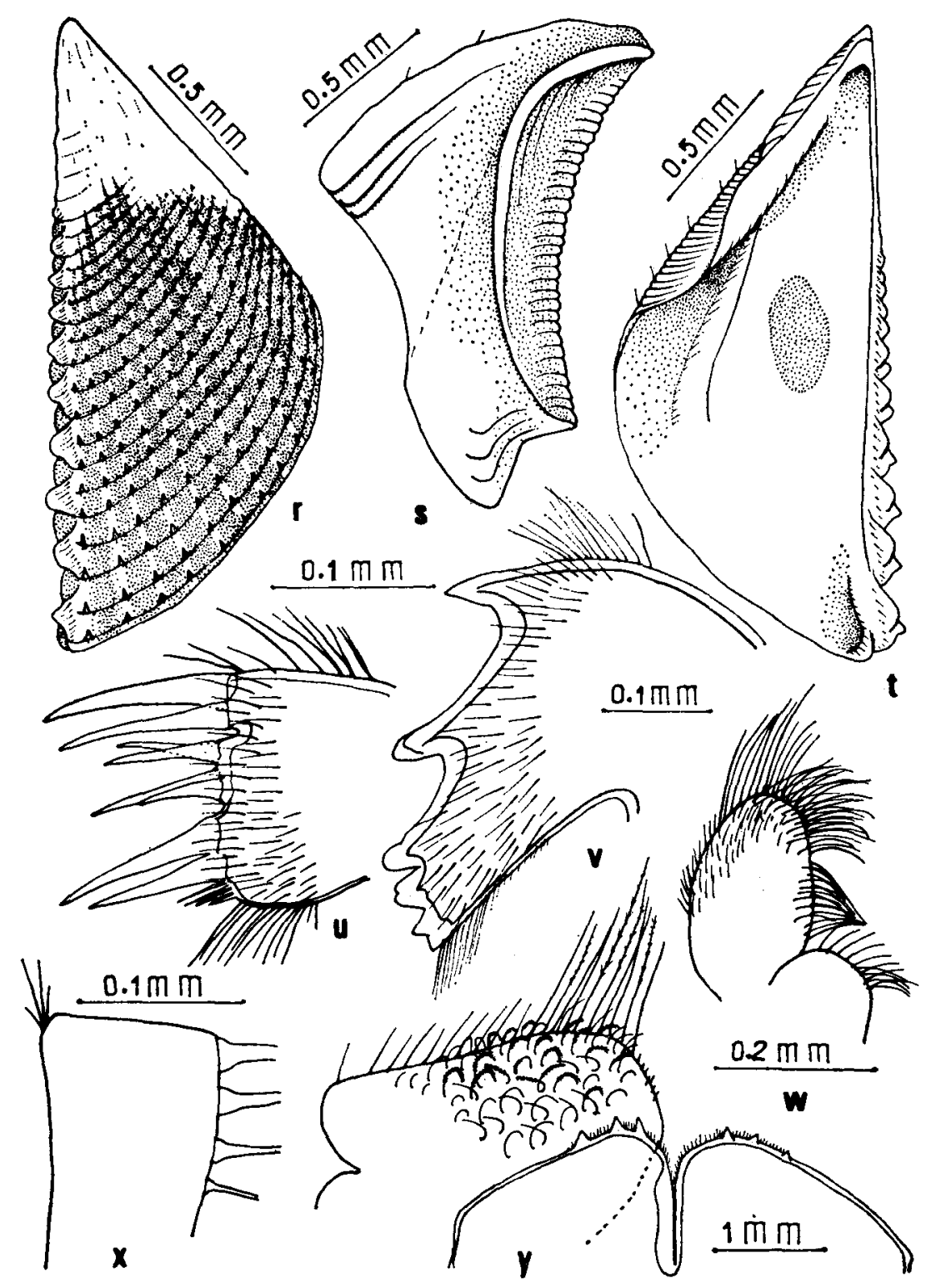

Fig. 2. Balanus (Chirona) tuberculatus sp. nov. Holotype. $r$, scutum, outer side view; s, tergum, inner side view; $t$, scutum, inner side view; $u$, maxilla $I$; $v$, mandible; $w$, maxilla $I I$; $x, 8$ th segment of anterior ramus of cirrus VI; y, labrum and palpus. 
3 pairs of setae and a non-porous calcareous basis as in $B$. taiwanensis.

Etymology. The specific name is based on the presence of bead-like tubercles on the external lamina of the compartmental plates.

Type specimens. Holotype, U.P. Crust. Coll. No. 280b-3. Trophi and cirri are mounted in gum arabic, shell plates and opercular valves in Riker mount. Paratypes, U.P. Crust. Coll. No. 280b-1. Soft body parts are mounted in gum arabic, hard parts are in Riker mounts. Several undissected specimens, No. 280b, are preserved in $80 \%$ alcohol.

\section{Family Tetraclitidae Gruvel, 1903}

\section{Genus Tetraclitella Hiro, 1939}

Definition. Shell generally less than $20 \mathrm{~mm}$ in rostrocarinal diameter, patelliform, ribbed; compartments discreet; parietes with 2 or more rows of tubes; radii broad, flush with or raised above parietal surface, summits horizontal, tubiferous, lacking teeth or denticles on articular surface; alae non-tubiferous; basis membranous, calcareous peripherally or wholly calcareous; scutum transversely elongated or higher than wide, commonly ornamented externally, lacking crests for depressor muscles; mandible with 5 teeth and spine-like lower angle; maxilla I with 6-8 major spines below subapical notch.

\section{Tetraclitella hyastina sp. nov.}

Fig. 3, r-v and Fig. 4, r-y.

Description. Shell dirty-white (Fig. 3, r) small, depressed conical, patelliform, with high-rise longitudinal granulated ribs extending well beyond the basal margin. There are 10-12 well developed ribs, 3 or 4 on rostrum, 2 or 3 on lateralia, 3 or 4 on carina. Horizontal growth lines distinct, hirsute. Radii and alae developed; summits of radii slightly depressed at the middle more or less forming an open Ushaped curve, externally longitudinally striated, permeated with obliquely arranged tubes; alae not permeated with pores, summits oblique. Orifice rhomboid to pointed ovate, carinal side acute, rostral side rounded, not toothed. Parietes permeated with a single or double rows of longitudinal tubes, first tube along ribs usually the largest, with additional ones along rib area beyond the basal margin (Fig. 3, u). Sheath broad about 2/3 of parietal wall with distinct horizontal growth lines, inferior edge slightly projecting, lamina below smooth. Basis thin, calcareous and poreless.

Sizes: carinorostral diameter; orifice, from $1.5 \mathrm{~mm}$ to $1.9 \mathrm{~mm}$; base (from tip to tip of ribs), from $4.7 \mathrm{~mm}$ to $5.7 \mathrm{~mm}$, (from rostral outer lamina to carinal outer lamina) from $2.6 \mathrm{~mm}$ to $3.8 \mathrm{~mm}$; height (lateral side), from $0.6 \mathrm{~mm}$ to $1.6 \mathrm{~mm}$. Carinal side higher than rostral side.

Scutum white, transparent, subtriangular, occludent margin longer than the tergal and basal margins, very slightly elongated along the basioccludent angle; basal margin slightly convex midway. Externally (Fig. 3, v) with a slightly raised hori- 
zontal growth ridges, finely hirsute; a median longitudinal depression present where a row of 5 to 6 minute holes are situated, in some there are additional minute pores (1 or 2) towards its occludent side (among the specimens examined, only on the left valve). Internally (Fig. 3, t) smooth with a longitudinal elevation medially coinciding with the external depression; articular ridge distinct with a sloping lower edge; articular furrow narrow and shallow; there is no adductor ridge; pits for the adductor muscles faintly indicated, for the depressor muscles indistinct; crests are obsolete.

Tergum white, transparent, subtriangular, externally flat without a spur fasciole;

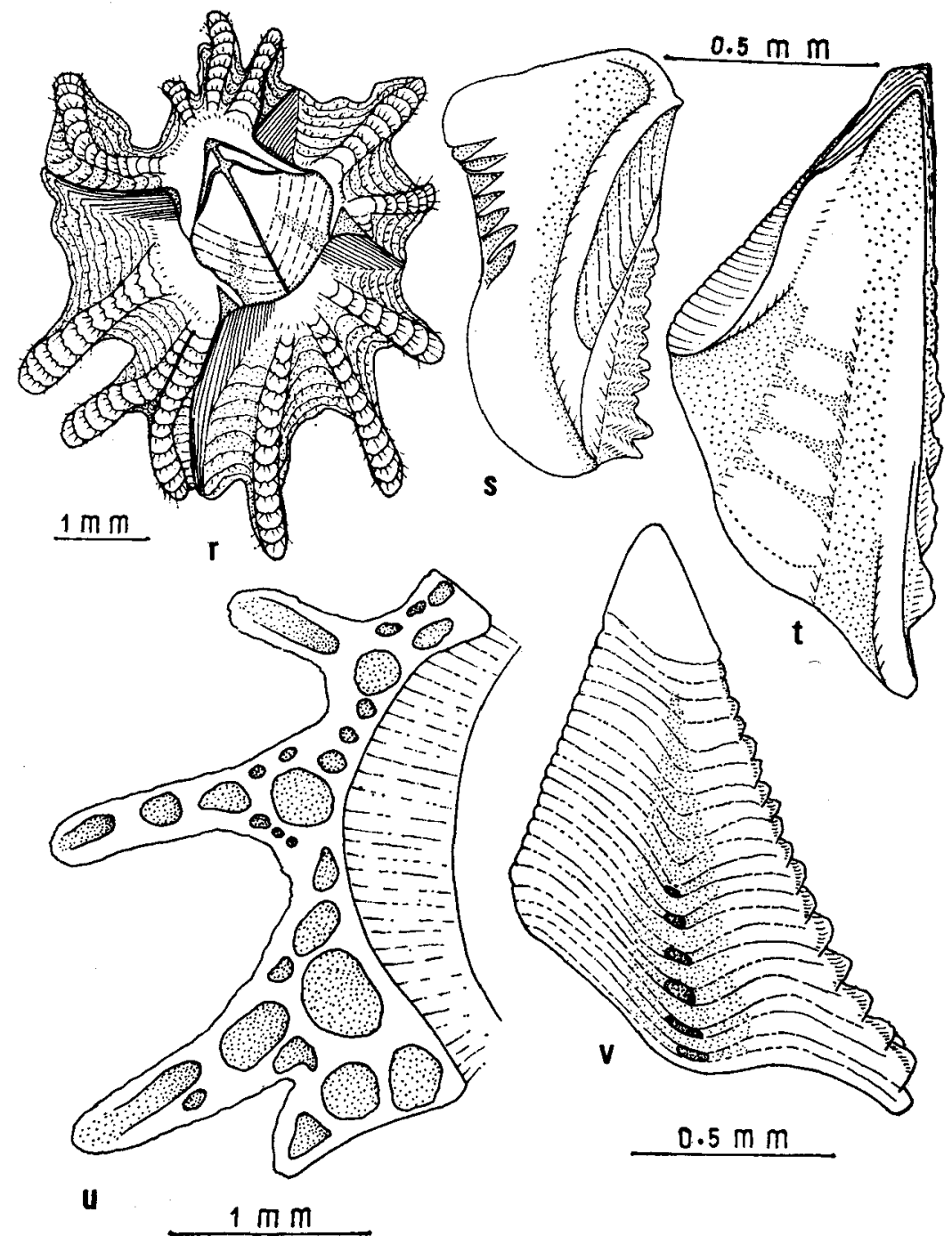

Fig. 3. Tetraclitella hyastina sp. nov. r, undissected animal; s, tergum, inner side view; t, scutum, inner side view; $u$, parietal tubes of carina, basal view; v, scutum, outer side view. ( $r$ \& $u$, holotype; s, t, \& v, paratype). 
scutal margin longer than the carinal margin, horizontal growth ridges are faintly indicated becoming more pronounced towards the scutal margin imparting a serrate appearance to this margin. Spur short about $1 / 2$ of the basal margin, transversely rounded confluent to the basiscutal angle. Internally (Fig. 3, s) smooth, scutal margin inflected; the articular ridge is prominent; the articular furrow broad and shallow; the crests for the depressor muscles are very distinct and are dependent on the margin.

The numbers of segments of the cirri:

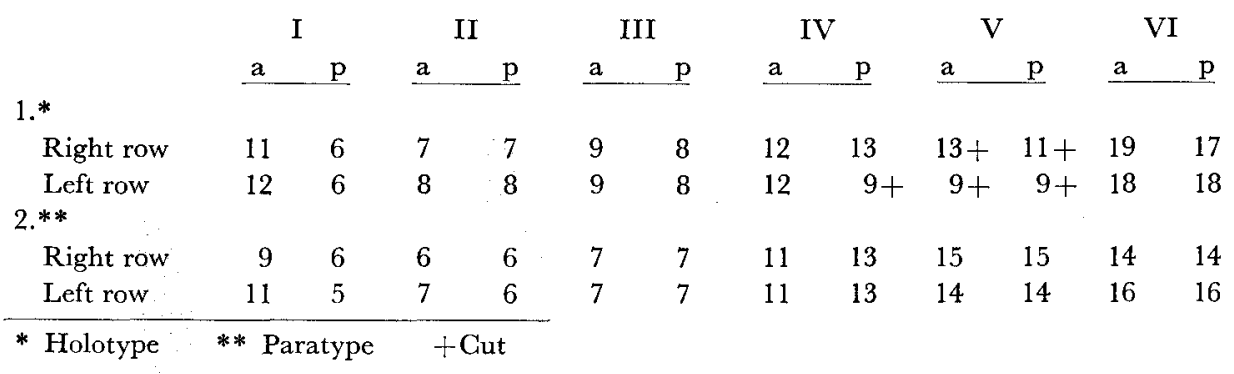

Rami of cirrus I unequal, anterior ramus longer, basal segments broad, upper segments slender, frontal margin with pinnate setae, those on upper segments are arranged in a circlet borne on the distal margin only; posterior ramus, basal segments are broader than the upper segments, the frontal margin of the intermediate segments are slightly protuberant with dense finely pinnate setae, on terminal segments are coarsely pinnate setae; posterior margin of lower pedicel of protopodite fringed with long finely pinnate setae, frontal margin destitute. Rami of cirri II and III are similar in appearance with more or less equal number of segments, however, the anterior ramus of either cirrus is actually 2 segments longer than the posterior ramus, frontal margin of intermediate segments are slightly protuberant and densely armed with finely pinnate setae; terminal segments of both rami with strong coarsely pinnate setae similar to those of the posterior ramus of cirrus I. In cirrus III, there are sharp spinelets on its frontal surface in addition to the subequal finely pinnate setae, more numerous on the anterior ramus. Cirri IV to VI similar, frontal margin of intermediate segments with 4 pairs of subequal sparsely pinnate setae with spinules between bases. Few minute spinelets are present too on its frontal margin of intermediate segments of the anterior ramus of cirrus IV. Penis moderately long or very short (Fig. 4, y), gradually tapering, annulated clothed with few short hairs becoming more numerous near the tip of the organ. No basidorsal point, however, in one specimen examined a midventral projection at the basal bend was observed.

Mouth parts. Labrum (Fig. 4, v) notched, margin with fine hairs, labral crests with 2 or 3 blunt denticles. Palpus club-shaped, outer margin setose, larger apical setae pinnate, short curved setae (Fig. 4, t) serrate. Mandible (Fig. 4, s \& u) with 5 teeth, 2nd and 3rd teeth usually with denticles on its upper margin, 4th and 5 th teeth more often well developed, oftentimes not very distinct and may appear only as bumps (Fig. 4, u) placed closed to each other and the inferior angle; 4th tooth 
usually with minute denticles on its superior margin; minute sharp spines are seated on the inferior angle, lowermost the largest. Maxilla I (Fig. 4, r \& w) notched below the 2 uppermost large spines, minute straight setae are seated on this notch; margin inferior to this notch straight supporting 5 or 6 spines, the 2 lowermost are larger than the intermediate ones; inferior angle rounded with few minute straight setae. Maxilla

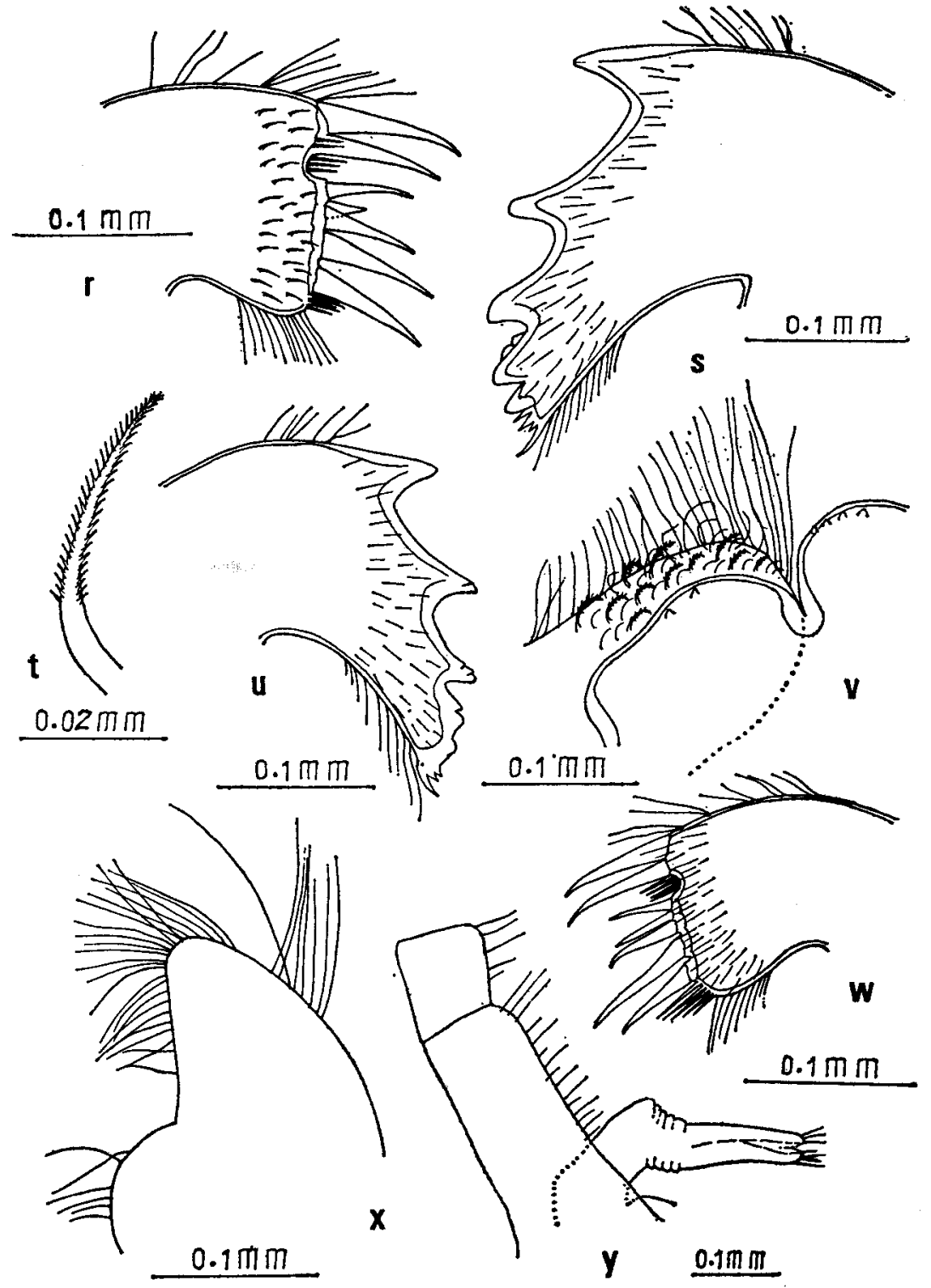

Fig. 4. Tetraclitella hyastina sp. nov. $\mathrm{r}$, maxilla $\mathrm{I}$; $\mathrm{s}$, mandible; $\mathrm{t}$, short stouter seta on palpus, enlarged; $u$, mandible; $v$, labrum and palpus; $w$, maxilla $I$; $x$, maxilla II; y, protopodite of cirrus VI with penis. ( $r, s, \& \mathrm{t}$, holotype; $u, v, w, x, \&$ y, paratype). 
II (Fig. 4, x) bilobed, upper lobe apically narrow with rounded edges, margin fringed with setae; lower lobe broad, frontal margin convex fringed with few small setae.

Habitat. Numerous (23) specimens were found attached to an undersurface of small intertidal rocks situated very close to the lowest low tide level where it remains always moist. Some were seated on the carapace of Hyastinus diacanthus, a brachyuran decapod, also an inhabitant of the same habitat together with C. moro, a juvenile empty shell of Balanus (Chirona) tuberculatus, a new species described just previously, and a juvenile Tetraclita sp. still with a single row of parietal tubes.

Remarks. The tetraclitellans could be divided into two major groups on the basis of the shape of the scuta, viz; 1) those with transversely elongated scuta, like $T$. chinensis, T. divisa, T. multicostata, T. purpurascens, T. karandei and T. digita; 2) those with subtriangular scuta, like $T$. darwini, T. pilsbryi and T. costata. The present form falls under the latter group, the scuta being subtriangular. However, the compartments, unlike the latter 3 species, have prominent hirsute granulated longitudinal ribs extending well beyond the basal margin imparting a decply notched basal rim. In this regard it is similar to multicostata and digita but the absence of the secondary riblets. Moreover, of the 3 known species with subtriangular scuta their compartments are permeated with numerous parietal tubes, while the present form only 1 or 2 rows. Basis is calcareous like darwini and costata, unlike pilsbryi whose basis is membranous.

Etymology. Specific name is based after a brachyuran decapod Hyastinus diacanthus where some of the individuals were seated on its carapace.

Type specimens. Holotype, U.P. Crust. Coll. No. 280a-5. Trophi and cirri are mounted in gum arabic, shell plates and opercular valves are in Riker mounts. Paratypes, U.P. Grust. Coll. No. 280a-1-3. Trophi and cirri are mounted in gum arabic, shell plates and opercular valves are in Riker mounts. Several undissected specimens, No. 280a, are preserved in $80 \%$ alcohol.

\section{Acknowledgments}

I wish to acknowledge with deep appreciation the use of a laboratory room and some other facilities extended to me by the U.P. Natural Science Research Council. Thanks goes to my research assistant, Mr. Feliciano R. Balcos, Jr.

\section{LITERATURE CITED}

Darwin, Ch., 1854. A monograph on the subclass Cirripedia: The Balanidae, Verrucidae, etc. vii-viii: 1-684. (Ray Soc., London).

Hiro, F., 1939. Cirripeds of Formosa (Taiwan), with some geographical and ecological remarks on the littoral forms. Mem. Coll. Sci. Kyoto Imp. Univ. Ser. B, 15 (2) : 245-284.

Hoek, C.C.P., 1913. Cirripedia of the Siboga Expedition. B. Cirripedia Sessilia. Siboga Expedite. monogr. $31 \mathrm{~b}: \mathrm{v}-\mathrm{xxv}, 129-275$. Leiden.

Newman, W.A., V.A. Zullo and T.H. Withers, 1969. Cirripedia, p. 206-295. In R.C. Moore (ed.) Treatise on Invertebrate Paleontology, vol. 1, part R: Arthropoda 4. Geol. Soc. America.

Nilsson-Cantell, Carl-Aug., 1921. Cirripedien-Studien. Zur Kenntnis der Biologie, Anatomie und 
Systematik diesser Gruppe. Zool. Bidrag fr. Uppsala, 7: 75-390.

Pilsbry, H.A., 1916. The sessile barnacles (Cirripedia) contained in the collection of the U.S. National Museum; including a monograph of the American species. Bull. U.S. Nat. Mus., 93: 1-366.

1927. Littoral barnacles of the Hawaiian islands and Japan. Proc. Acad. Nat. Sci. Philadelphia, 79: 305-317.

Rosell, N.G., 1975. A new Tetraclitella (Cirripedia Thoracica) from the Philippines. Crustaceana, 28(1): 96-100.

Ross, A., 1969. Studies on the Tetraclitidae (Cirripedia, Thoracica): Revision of Tetraclita. Trans. San Diego Soc. Nat. Hist., 15(15): 237-251.

1971. Studies on the Tetraclitidae (Cirripedia Thoracica): A new Tetraclitellan from India. Ibid., 16(8): 215-224.

Utinomi, H., 1962. Thoracic cirripeds from western Kyusyu. Publ. Seto Mar. Biol. Lab., 10(2): 211-239. 